\title{
SYSTEMATIZATION OF METHODS AND MODERN TECHNOLOGIES OF INTERRELATIONS BETWEEN BANKS AND CLIENTS MANAGEMENT IN UKRAINE
}

\author{
Oleh Kolodiziev \\ Department of Banking \\ Simon Kuznets Kharkiv National University of Economics \\ 9-a Lenina ave., Kharkiv, Ukraine, 61166 \\ kolodizev107@ukr.net \\ Olena Kotsiuba \\ Financial Department \\ Simon Kuznets Kharkiv National University of Economics \\ 9-a Lenina ave., Kharkiv, Ukraine, 61166 \\ kotsiuba_elena@mail.ru
}

\begin{abstract}
Interrelations with clients are the basis of banking system functioning. But in the process of attracting new customers banks should pay attention to avoiding high credit risk and money laundering risk. Theoretical aspects, practical methods and modern technologies of serving customers are considered and systematized in the article. The main marketing tools to strengthen relationships with loyal customers and attract new clients are branding, multi-service package with discount rates and lower fees, price, distribution channels and providing unique services. According to the NOCKS FISHES Company's research, the information of marketing innovations or internal communications is barely illustrated in the publications. In the present circumstances there is a need to increase the responsibility of experts for the accuracy of information and results of analytical reviews of economic forecasts. The eventual risks by broadening access technology for customers are recognized. There are presented suggestions how to increase efficiency of interrelations between clients and banks in the article.
\end{abstract}

Keywords: CRM-system, “client-bank” system, banking marketing.

(C) Oleh Kolodiziev, Olena Kotsiuba

\section{Introduction}

During the financial and economic crisis, domestic banks aim at maintaining loyal customers and existing positions at the market. Because of lower community trust to the banking system, in the terms of strengthening the control of the National Bank of Ukraine national banks management turns its attention to the development of new and effective mechanisms that will provide the expansion of the customer base and improve customer service.

There was given analysis of the current problems, today there is an urgent necessity of deepening the theoretical approaches and improving existing methods and management technologies of interrelation between a bank and clients.

These domestic and foreign scholars as Armstrong G., Bondarenko A. F., Kosenko V. I., Kovalenko V. V., Kotler F., Maydebur E. V., Mishchenko V. I., Rozkoshna O. A., Tahyrbekov K. and others dedicated their scientific work to developing practical recommendations, particularly to researching the fields of customer strategy and marketing policy in banks.

The aim of the article is to summarize and systematize existing theoretical approaches, practices and modern management technologies of interrelation between the bank and clients in the movement of strengthening community trust to the domestic banks and increasing their profitability.

\section{The necessity of developing interrelations between clients and bank}

Efficiency of the banking system depends strongly on the quality of interrelations with clients. This fact is practical valid. Regarding quantitative statistical measurement of the compo- 
nent - activity quota of investing borrowed funds into the credit portfolio of the Ukrainian banking system on the 01.04 .2015 year is $85.30 \%$, and the rate of credit activity is more than $80 \%$. These facts indicate aggressive credit activity of financial institutions in general and the substantial growth of credit risk.

In order to create the necessary conditions for stabilizing the system, banks management should not only pay attention to optimizing relationships with loyal customers but also to reducing the customer's credit risk and money laundering risk.

IBM and the analytical department of publishing house Economist conducted the survey of experts-employees of leading financial institutions. The results showed that the financial companies and banks need to deepen relationships with customers, to create differentiated products and to focus on innovations.

Due to the fact that the banking sector offers the same products that differ only at the price and quality of service, the problem of improving interrelations with clients is relevant. A clear regulatory policy of the NBU limits the differentiation of banking services. Therefore, banks should use marketing tools to strengthen relationships with loyal customers and attract new clients. The means to achieve this goal are:

- branding, which promotes awareness of customers about the services offered by the bank;

- multi-service package that offers discount rates on credit or lower fees for payment and cash services under certain conditions;

- price which is the main determinant of demand for banking products. It should be noted that the rapid devaluation of the hryvnia and foreign exchange restrictions, the price of the currency and its presence in banks is also one of the ways that can attract customers;

- distribution channels that allow banks to directly sell their products. This can be both online banking and direct contact with customers;

- providing unique services or innovative technologies servicing.

According to A. Vitrenko's opinion [1,2], due to the relatively high degree of commonality of banking services and due to strict government regulation of the banking system advertisement is the only tool in the competition for customer's dollar. As a result, the banking advertisement market is quite spacious. The banks are second only to manufacturers of food products, cosmetics and hygiene products considering the advertising budgets. Indeed, there has been a tendency to increasing quantity of banking advertisement for recent years. It is often used entirely inappropriate and unjustified. Promotional activities of banks should be focused on meeting the following objectives:

- informing customers about the existence of a banking institution;

- informing customers about service quality and speed in this banking institution;

- creating a positive image of the bank, including its positioning as a strong and stable bank.

Among effective means of advertising campaigns there are advertising in the media, direct advertising (advertising by phone, mail, cards), advertising on the place of contact with the consumer.

NOKS FISHES Company regularly conducts researches in the field of media and publishes ratings of media-activity of the banks [3]. So at the beginning of 2016, the most frequently mentioned banks in the media were JSC "Savings Bank", PJSC "Ukreximbank", PJSC "CB "Privatbank", PJSC "Ukrsotsbank" and PJSC "Raiffeisen Bank Aval”. In 2015 the group of the most frequently mentioned banks in the media was different. Thus, the leaders became PJSC "First Ukrainian International Bank", PJSC "Nadra Bank" and PJSC "Platinum Bank". However, the interesting fact is that internal or even details of top-manager's private life appear in the media most often (Fig. 1). At the same time the information of marketing innovations or internal communications is barely illustrated in the publications.

In our opinion, the public information should support the bank's reputation and strengthen banks' credibility. Therefore, in the present circumstances, there is a need to increase the responsibility of experts for the accuracy of the information and results of analytical reviews of economic forecasts. 


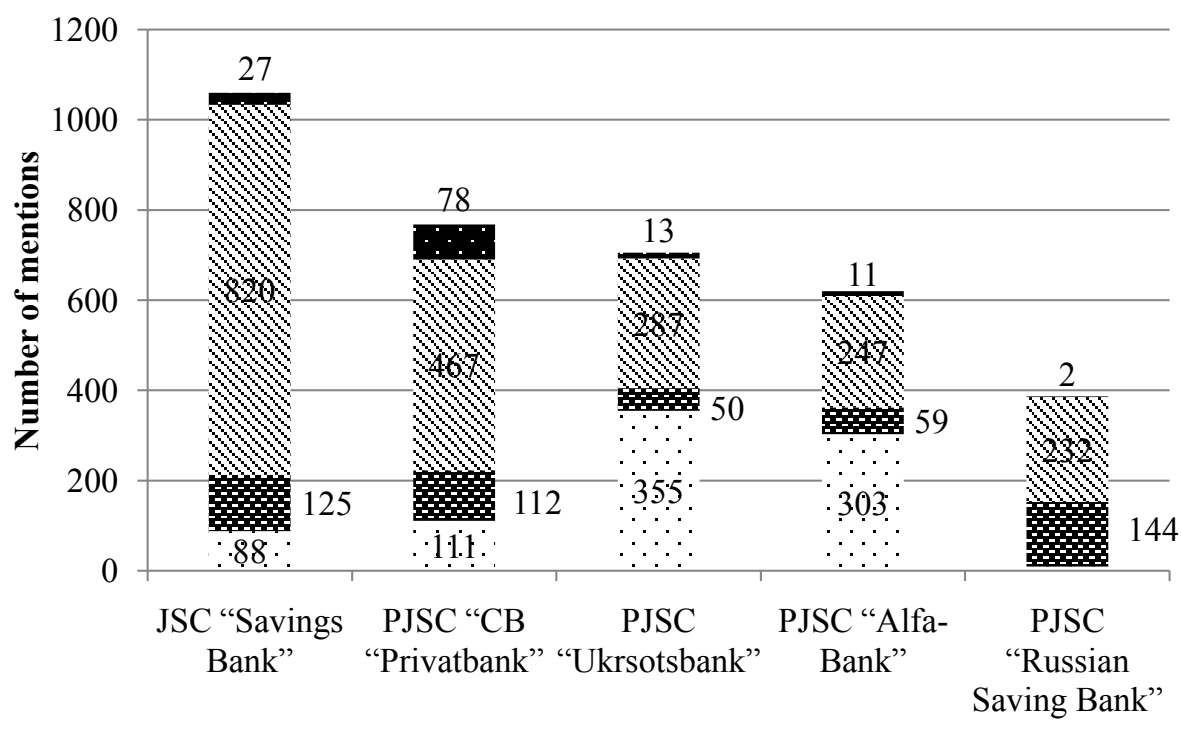

- Business $₫$ Services $\aleph$ Internal communications $\mathbf{a}$ Marketing and innovations

Fig. 1. Media-activity of the most mentioned banks in the media at the beginning of 2016

\section{Reasons of low banking service quality and ways to improve it}

In the area of customer service one of the main problems of the banks is an unsustainable and separated organizational structure. Thus, departments of banks pay attention and work only with their own segment of customers. Marketing service departments are classified by products that are aimed at the specific groups of customers. To solve this problem the bank's management should provide the whole automation of the system of interrelations with bank customers and develop various forms of remote customer service.

To maintain qualified and efficient contact between customer and manager of the bank department there should be a full characteristic of a client (from his behavior and habits to his ability to pay, and credit or deposit history). Furthermore, it is important to have information that will allow to qualify customers according to criteria, categories etc. Today, combining these types of information is possible through the CRM-systems (Customer Relationship Management). Functionally CRM can be presented in the form of large modules - Automation Marketing (analysis and creating the target client audience, database of banking products, interest rates, market and competitors conditions, planning and conducting marketing campaigns, analyzing their results, creating tools for online marketing; personalized «one-to-one» marketing using modern channels of information collection and database etc.) and Automation of Banking Services (prediction banking operations, contact management, customer's assistance, building customer bases and price sheets, analysis of profit and losses etc.) [4].

The CRM-system makes suggestions to clients that are relevant to their needs and serves customers basing on their individual characteristics. Most often in the specialized literature there are presented classification of the CRM-systems in terms of the functions they perform. In particular, A. Karminsky, E. Payne, B. Chernikov, S. Shovkoplyas, L. Synylo M. Kadykov, A. Lidovska allocate operational, analytical and collaborative CRM-system. Analysis of sources [5-7] made possible to organize tasks that can solve the above mentioned types of the CRM-systems in the Table 1.

It should be noted that CRM is broader than traditional automated banking system. Implementation of CRM is not limited by the sequence of stages of the adoption of the new software platform. It needs the changes of collaborators mentality, reorganization of business processes, reorientation to customers, re-employment of working places of employees who directly interact with customers, decentralizing the functions of bank marketing etc. 
Table 1

Systematization of tasks, which are solved by different types of the CRM-system

Types of the

\footnotetext{
Operative - building up the history of the relationship with each customer;

- rapid access to information of each client;

- improving business processes with a focus on the customer.
}

- automation of phone sales and customer service;

- search, storage and organization of clients databases and information about interrelation with them;

- synchronization of different data sets;

Analytical - analysis and interpretation of statistical laws to improve sales strategy and customer service etc.;

- decision support systems;

- developing mechanisms of increasing sales by encouraging customers interest and loyalty.

- attract customers to the creation or improvement of banking services;

- organization of customer self-service through web-sites;

- interactive access to information of various banking departments;

Collaborative

- networking customers with the bank through various channels (phone, Internet, personal contact, etc.);

- integration of various information services and infrastructure, providing cooperation between

clients, bank and its employees.

Effective CRM-strategy must correspond with the mission of the bank and be linked to the goals of the business. In this case information technology plays only a supporting role. Each bank must independently choose the automation tools which are the most effective for it at the different stages in interrelation with customers [8].

In Ukraine banks that use CRM-systems prefer only operational types because of the high cost of implementation. In the early 2000-s, the cost of 1 license for 1 user reached $\$ 3000$ [9]. In 2009 this figure amounted to $\$ 1000-1500$, today $-\$ 800$ [10]. The analysts forecast reduction of the licenses cost for $\$ 500$ in 2020. Innovation within these systems will cost more expensive that makes impossible to use them. Currently the ratio of operational, analytical and collaborative CRM-systems is 90:9:1.

Today the number of banks that use different technologies of customer service increased in Ukraine. However, the majority of domestic banks prefer borrowing innovation rather than developing their own. Along with the problem of optimizing and improving service quality of loyal clients there appears the problem of attracting new customers that requires certain investments (Fig. 2).

Popular types of banking are: mobile, phone, Internet banking and "client-bank" system. According to the banking analysts' research, employees of the enterprise are turning to the bank to 15 times per day. The "client-bank" system saves bank staff's and employees' time. Some banks such as PJSC CB "Privatbank", PJSC "Ukrsotsbank", PJSC "Raiffeisen Bank Aval” added the ability to use Internet. That allows clients to connect to services rapidly and without installing software.

Among the most affordable methods of attracting new customers is a "word of mouth" which is the recommendations of clients who are long and successfully served in the bank; bank staff's advices to their own friends and relatives; advertisement of banking services at specialized conferences, exhibitions; SMM-management and sending emails and messages with offers of new banking products, promotions and discounts (direct-mail). 


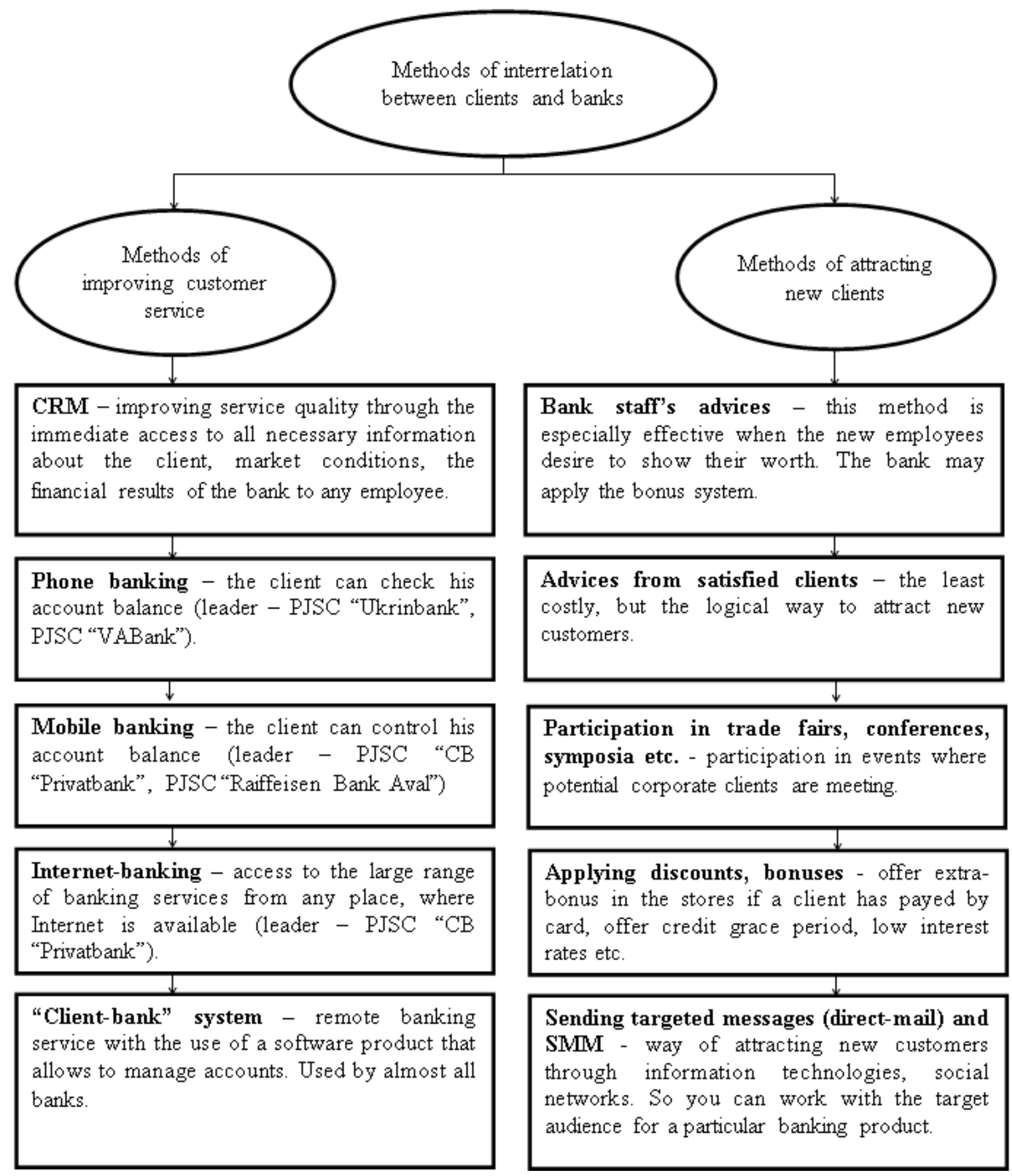

Fig. 2. Characteristic of modern methods of keeping interrelations between banks and clients

\section{Potential risks by developing interrelations with clients}

In our opinion, banks should pay attention to the methods and technologies that are aimed at improving the quality of customer service. Attracting new customers is not a priority because the population in Ukraine is gradually reduced and the number of customers who haven't had a bank account yet is close to zero. But trying to improve service quality banks must constantly monitor the size of the customers' risks, such as credit risk and the risk of money laundering or terrorism financing.

According to the Resolution of the National Bank of Ukraine "On Approval of the Financial Monitoring by Banks” № 417 dated 26.06.2015, the risk of use of banking services for money laundering or terrorism financing - existing or potential danger (threat, vulnerabilities) of increasing 
legal risks and/or reputation of the bank risks and the bank's risks may be used for the purpose of money laundering/financing of terrorism at the service time [11].

According to the State Committee for Financial Monitoring of Ukraine Order "On Approval of risk criteria of crime money laundering or terrorism financing” № 126 from 03.08.2010, the criteria for the evaluation of risk by customers and by type of goods and services are determined.

\section{Recommendations for improving the efficiency of marketing communications}

It is different for banks depending on the size. Table 2 shows systematized recommendations for the different groups of banks.

Thus, the results of the research allow make conclusions that confirm the general trend which is the implementation of active marketing policy of the bank and the introduction of modern technologies can improve customer service as a key goal of banks. It should be noted that implementation of the marketing policy tools is important for banks of all sizes.

Table 2

Ways of increasing efficiency of marketing communications in banks

- extension of existing marketing departments with the inclusion of departments which deal with potential customers, marketing communications, press services, and coordination of branches;

Large - creation of common databases of customers with the use of CRM-systems;

- regular monitoring of the environment, the needs of customers;

- cooperation with scientific institutions, high-schools to develop effective marketing policy;

- permanent support of financial stability and reputation of the bank for improving customers loyalty.

- establishment or expansion of marketing department;

- working out of codes, memorandums, communications policy rules;

Average - carrying out market researches of the needs and desires of potential, new and loyal customers;

- improving existing or creating new web site;

- introduction of a system on a twenty-four hour basis of consultations with managers with the use of leading information technology.

- establishment of marketing department;

- expanding the client base by reducing the cost of banking services compared to large banks competitors;

Small - introduction of new banking services with the low cost;

- Increasing costs for marketing communications;

- development and providing of the corporate identity.

\section{Conclusion}

The special significance of this process is arisen under the present circumstances by the deterioration of economic conditions, reducing the financial stability of the banking system that leads to the decrease of community trust and customers loyalty. But trying to expand its customer base bank management should ensure a high level of financial security, especially relative to solutions of reducing the levels of credit risk and the risk of money laundering or terrorism financing.

\section{References}

[1] Dyba, M., Danylyuk, Ye. (2012). CRM-systemy v marketynhoviy politytsi banku. Marketynh v Ukrayini, 4, 18-24.

[2] Vytrenko, A. (2012). Osobennosty rynka reklamnykh usluh y eho mesto v obshchenatsyonal'nom rynke. Visnyk Kyyivs'koho Natsional'noho Universytetu im. T. H. Shevchenka, 132, 46-49.

[3] Official web-site of NOKS FISHES Company. Available: http://noksfishes.com.ua/

[4] Bondarenko, A. F., Rozkoshna, O. A., Kosenko, V. I. (2013). Suchasni aspekty rozvytku kliyentynh-stratehiyi banku. Biznes-inform, 3, 313-318. 
[5] CRM hlazamy Darvyna: Evolyutsyya klyent-oryentyrovannykh tekhnolohyy. (2006). CRM konsul'tant, 1, 6-11.

[6] Karmynskyy, A. M. (2006). Ynformatsyonnye systemy v ekonomyke. Praktyka yspol'zovanyya. Fynansy ta statystyka, 336.

[7] How companies approach innovation: A McKinsey Global Survey. Available: http://www.mckinsey.com/featured-insights

[8] Kl'oba, L. H. Marketynhovi aspekty vdoskonalennya upravlinnya bankivs'koyu diyal'nistyu. Official web-site of National University “Lviv Polytechnic” Repositary. Available: http://ena.lp.edu.ua:8080/ bitstream/ntb/11394/1/54.pdf

[9] Yskusstvo ekspluatatsyy CRM. Available: http://www.prostobankir.com.ua/it/stati/iskusstvo ekspluatatsii_crm

[10] Official web-site of Microsoft Dynamics CRM. Available: http://crm-consulting.com.ua/

[11] Postanova Pravlinnya Natsional'noho banku Ukrayiny «Pro zatverdzhennya Polozhennya pro zdiysnennya bankamy finansovoho monitorynhu» vid 26.06.2015 № 417. Available: http://zakon3.rada.gov. ua/laws/show/v0417500-15

\title{
ASEAN TENDENCY TO THE REGIONAL LEADERSHIP IN TRADE IN SERVICES
}

\author{
Oleksandr Krinitsyn \\ Department of the world economy and international economic relations \\ Institute of international relations, Taras Shevchenko national university of Kyiv \\ 36/1 Melnikova str., Kyiv, Ukraine, 04119 \\ krinitsyn.alexander@gmail.com
}

\begin{abstract}
Extremely dynamic and significant structural changes are transforming the world economy and international trade. Comparing with analogous experience of economic history it is worth to pay attention not only to the fast speed of global transformation but also to its wide scope that influences practically the whole world.

The shift of economic power from West to East and from North to South, from industrially developed countries to the developing ones, especially Asian, is the obvious base of these transformations. In contrast to the world tendencies of the 20 -th century with two dominant centers namely USA and EU, in the 21-st century the developing Asian countries with more dynamics of development rise on the global arena.

Economies of Association of Southeast Asian Nations (ASEAN) are not an exclusion from these tendencies. Whereas their speed growth in the last four decades was conditioned by high level of industrial production export, the services sector and trade in services began to gain importance not so long ago.

Association of Southeast Asian nations unites ten countries with total population more than 622 million people and total GDP more than 2.6 trillion US dollars. These countries are well integrated into the world economy and successfully gain profit from this integration.

In particular the ASEAN integration helped to raise regional trade flows without trade diversification, to improve trade logistics, to decrease total trade costs and to increase regional investment flows.

The article deals with analysis of values, dynamics and structure of trade in services in Association of Southeast Asian Nations.

A complex analysis of trade in services with respective breakdown into separate branches was carried out. This article analyzes the importance of complex legal-regulatory measures for successful promotion of trade in services within the region as well as with the rest of world.

Keywords: international trade, trade in services, liberalization, Association of Southeast Asian Nations, ASEAN, ASEAN Framework Agreement on Services, AFAS.
\end{abstract}

